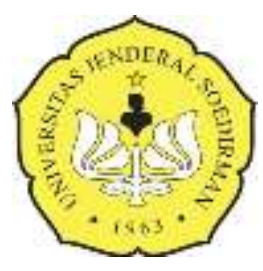

PAJU Volume 1 Nomor 12019

PHYSICAL ACTIVITY JOURNAL

http://jos.unsoed.ac.id/index.php/paju

\title{
Komponen Biomotor Dominan Pada Permainan Tradisonal Dul-Dulan Khas Banyumas
}

\author{
Indra Jati Kusuma1, Panuwun Joko Nurcahyo², Galih Noor Alivian³ \\ 1,2,3 Fakultas IImu-IImu Kesehatan, Universitas Jenderal Soedirman, Indonesia \\ email: indrajaks2122@gmail.com ${ }^{1}$, panuwunjoko@gmail.com² \\ DOI: https://doi.org/10.20884/1.paju.2019.1.1.2000
}

\begin{abstract}
Abstrak
Penelitian ini bertujuan untuk mengetahui unsur-unsur komponen biomotor dominan yang terkandung dalam olahraga permainan tradisional dul-dulan khas banyumas. Metode penelitian menggunakan metode kualitatif dengan pendekatan deskriptif kualitatif. Pengumpulan data menggunakan observasi, wawancara dan dokumentasi. Sampel penelitian anak sekolah menegah atas usia 15-17 tahun yang memenuhi kriteria berjumlah 20 anak (10 laki-laki dan 10 perempuan). Data direkam dan dianalisa dengan ahli pembelajaran penjas dan analisa gerak untuk mendapatkan komponen biomotor dominan. Hasilnya pada permainan dul-dulan unsur biomotor yang dominan adalah daya tahan (aerobik dan anaerobik), kekuatan dan daya tahan otot tungkai, kecepatan lari, kecepatan reaksi, koordinasi mata tangan, serta kelincahan. Dalam permainan tradisional merupakan betuk aktivitas fisik yang murah dan mudah untuk dilaksanakan selain itu juga memberikan rasa kegembiraan. Adanya keterlibatan unsur-unsur biomotor dominan yang berbeda-beda, menjadikan permainan tradisional dapat digunakan dalam melatih unsur biomotor yang diperlukan.
\end{abstract}

Kata Kunci: Dul-dulan, Komponen Biomotor, Banyumas

\begin{abstract}
This study aims to determine the elements of the dominant biomotor components contained in traditional game sports in the first place typical of Banyumas. The research method uses qualitative methods with a qualitative descriptive approach. Data collection uses observation, interviews and documentation. The research sample of middle school children over the age of 15-17 years who met the criteria amounted to 20 children (10 boys and 10 girls). Data is recorded and analyzed by physical education learning experts and motion analysis to obtain dominant biomotor components. The results in the dominant game of biomotor elements are endurance (aerobic and anaerobic), strength and endurance of leg muscles, running speed, reaction speed, hand eye coordination, and agility. In traditional games it is a form of physical activity that is cheap and easy to carry out besides it also gives a sense of excitement. The involvement of different dominant biomotor elements makes traditional games can be used in training the required biomotor elements.
\end{abstract}

Keywords: Dul-dulan, Biomotor Components, Banyumas

\begin{tabular}{|c|c|c|}
\hline Alamat Koresponden & : $\quad$ Prodi PJKR Fakultas Ilu-Ilmu Kesehatan Unsoed & $\begin{array}{ll}\text { e-ISSN } & : 2686-5807 \\
\text { p-ISSN } & : 2686-5793\end{array}$ \\
\hline $\begin{array}{l}\text { E-mail } \\
\text { No. Telp./Hp }\end{array}$ & : indrajaks2122@gmail.com & \\
\hline
\end{tabular}




\section{PENDAHULUAN}

Salah satu bentuk aktivitas gerak adalah bermain. (Naisaban, 2007) menyatakan bahwa sejak lahir sampai dengan usia dua tahun seorang anak sudah mulai bermain. Menurut (Lutan, 2005) bermain adalah hal yang paling penting untuk mengembangkan biomotoranak-anak. Dapat dikatakan bahwa bermain merupakan sesuatu yang sangat dibutuhkan dan berperan penting bagi setiap orang. Di kabupaten Banyumas terdapat banyak permainan tradisional.yang tersebar di berbagai desa. Jenis permainan tradisional yang tersebar di berbagai pelosok desa di banyumas dapat dimainkan di siang hari, malam hari, dan ada yang dimainkan didaerah Sungai Serayu. (Aneka Permainan Tradisional Khas Banyumas .http:// travel. kompas.com.).

Pada permainan tradisional biasanya terdapat kekhasan, baik dari segi model maupun dari segi keterlibatan otot tubuh kita. Permainan tradisional khas Banyumas seperti dul-dulan, saat ini sudah jarang yang memainkannya. Pada kurikulum di sekolah, permainan tradisional sudah dikenalkan sejak tingkat sekolah dasar. Meskipun telah dikenalkan di tingkat Sekolah Dasar, namun permainan tradisional tidak banyak dimainkan dan sampai saat ini kemampuan biomotor dominan yang dapat mendukung pengembangan kemampuan motorik anak dari permainan tradisional, belum banyak kajian yang mengungkap hal tersebut. (Kusuma \& Julianti, 2015) menjelaskan bahwa komponen biomotorik meliputi kecepatan (speed), kekuatan (strength), kelentukan (flexibility), daya tahan (endurance) dan koordinasi (coordination)

Kemampuan bimotor merupakan salah satu aspek penting untuk dapat menunjang seseorang menccapai tujuan yang diinginkan pada suatu gerakan. (Candrawati et al., 2017) menjelaskan bahwa kondisi fisik terkait komponen biomotor merupakan aspek penting untuk meraih prestasi. Prestasi dalam hal ini meliputi banyak faktor, keterampilan gerak juga merupakan prestasi yang dapat diukur dibidang olahraga, dengan menggunakan tes keterampilan biomotorik.

Keterampilan gerak dan komponen biomotor yang terdapat dalam olahraga tradisional dul-dulan sampai saat ini belum ada yang mengkaji, apakah dapat meberi dampak positif terhadap perkembangan motorik anak atau tidak, sehingga perlu dikaji lebih mendalam untuk mendapat menfaat dari olahraga tradisional tersebut. Padahal apabila generasi muda sering memainkan olahraga permainan tersebut dikehidupan sehari-harinya, diharapkan dapat mengembangkan kemampuan motoriknya. Tujuan penelitian ini adalah untuk dapat diketahuinya unsur-unsur komponen biomotor dominan dalam olahraga permainan tradisional dul-dulan sehingga dapat menjadi bahan rreferensi dan kajian keilmuan mengenai manfaat olahraga tradisional dari segi komponen biomotorik. 


\section{METODE}

Penelitian dilakukan di desa Tambaknegara Kecamatan Rawalo Kabupaten Banyumas. Metode penelitian yang digunakan dalam penelitian ini yaitu menggunakan pendekatan deskriptif kualitatif (Thomas \& Nelson, 2001). Penelitian deskriptif kualitatif merupakan penelitian yang termasuk dalam jenis kualitatif. Populasi yang digunakan dalam penelitian ini adalah anak remaja sekolah menengah atas (1517 tahun) di wilayah desa tambaknegara kecamatan rawalo kabupaten banyumas. Teknik pengambilan sampel dilakukan secara purposive sampling dengan kriteria inklusi. Kriteria inklusinya; 1) Anak Sekolah Menengah usia 15-17 th tahun di grumbul kalibacin, desa tambaknegara, banyumas. 2). Sehat jasmani dan rohani ,3). Telah menerima materi pembelajaran olahraga permainan tradisonal. Sampel berjumlah 20 anak sekolah menengah usia 15-17 tahun yang terdiri atas 10 laki-laki dan10 perempuan.

Pengambilan data penelitian dilakukan dengan cara observasi, wawancara diskusi kelompok dan simulasi yang didokumentasikan melalui foto, video (Safari, 2010). Data yang diperoleh dianalisis secara deskriptif kualitatif oleh 2 orang pakar (ahli pembelajaran penjas dan analisa gerak)

\section{HASIL DAN PEMBAHASAN}

\section{a. Observasi}

Observasi telah dilakukan di Desa Tambaknegara Kecamatan Rawalo Kabupaten Banyumas. Tahapan ini dilakukan untuk mendapatkan informasi tentang kondisi populasi sasaran, karakteristik dan unggulan objek wisata yang dikembangkan, potensi obyek wisata yang belum dikembangkan, serta peluang pengembangan olahraga tradisional sebagai alternatif daya tarik wisatawan.

Pada tahap ini dilakukan penggalian informasi terhadap pegiat wisata di Desa Tambak Negara Kecamatan Rawalo Kabupaten Banyumas. Wilayah ini dipilih karena desa ini telah mengembangkan desa tersebut sebagai Desa Wisata dan sudah mendapatkan pembinaan kepariwisataan oleh Dinas Pariwisata Banyumas.

1). Profil Desa Tambaknegara

Desa Tambaknegara secara administratip wilayah terletak di kecamatan Rawalo Kabupaten Banyumas Propinsi Jawa Tengah. Desa ini terletak paling timur dari kecamatan Rawalo terletak dijalan lintas tengah antara Kota Purwokerto dan Cilacap. Desa ini berbatasan antara lain sebelah selatan dengan Desa Losari kecamatan Kebasen dipisahkan oleh aliran sungai serayu, sebelah timur dengan Desa Notog Kecamatan Patikraja di sebelah barat dengan Desa Rawalo, Pesawahan, Dan Sidamulih sebelah utara dengan Pegunungan Milik Perum Perhutani. 


\section{2). Pofil Penduduk Desa Tambaknegara}

Penduduk yang tinggal didesa ini pada umumnya masih memiliki hubungan kerabat antara satu penduduk dengan penduduk lainnya, apalagi bila kita melihat lebih sempit dalam satu RT misalnya bisa saja mereka masih satu turunan, terasa sekali rasa kekeluargaan di sini, halinilah yang menyebabkan daerah ini sangat tentram dan damai meski ada bermacam penganut agama dan sosial yang berbeda.

Desa Tambaknegara ini pada hari biasa, nampak terlihat agak sepi, kalau kita bisa menelisik lebih jauh dapat kita lihat sebagian besar penduduknya diatas umur 50 tahunan, ibu muda, anak usia sekolah dan balita, sedikit kita jumpai warga dengan usia produktif, kalaupun ada itu merupakan perangkat desa, PNS, atau orang yang benar-benar ulet dan sebagian besar lainya adalah orang usia produktif yang kurang berpendidikan dan atau tidak mempunyai ketrampilan tertentu hingga tidak mampu bersaing diluar. Kemana yang lainya kebanyakan karena alasan ekonomi penduduk pada usia produktif pergi merantau kekota-kota besar dipenjuru tanah air. Jumlah penduduk sebenarnya dapat kita lihat dan rasakan ketika libur-hari raya lebaran.

\section{3). Potensi Wisata Desa Tambaknegara}

Mengenai asal usul Tambaknegara belum banyak orang yang tahu dan siapa tokoh yang dahulunya memberi nama ini. Sekilas barangkali Tambakwaringin atau Kalibacin yang menjadi cikal bakal penamaan desa Tambaknegara, wallahu alam. Letak geografisnya cukup luas dibanding desa-desa lain di Kecamatan Rawalo, diujung timur/utara berbatasan dengan desa Notog Kecamatan Patikraja, diujung barat berbatasan dengan desa Rawalo, diujung barat utara berbatasan dengan desa Sidamulih ke arah selatan berbatasan dengan sungai serayu dengan seberang daratannya desa Gambarsari kec. Kebasen. Dari Grumbul Karangdadap, Kalitanjung, Bonjok Kulon, Bonjok Wetan dan Kaliwangi/Wadastumpang terhampar seluas $892.508 \mathrm{~m} 2$, terdiri dari daratan, perumahan, pekarangan, pesawahan dan tanah Perhutani. Di Kecamatan Rawalo mungkin hanya Tambaknegara yang paling minim tanah persawahannya dibanding tanah darat dan pegunungan. Dengan jumlah penduduk kurang lebih 7260 jiwa cukup padat untuk ukuran sebuah desa, di kabupaten Banyumas

Tambaknegara memang unik, ada 5 grumbul, terbagi 4 dusun, yakni Kalitanjung, Kaliwangi, Karangdadap dan Bonjok. Bonjok Wetan Bonjok Kulon dipimpin oleh seorang Kadus (kepala dusun) dibawah Kades (kepala desa), Kaliwangi, Kalitanjung dan Karangdadap masingmasing satu Kadus, dibagi menjadi 7 RW. Apabila dilihat dari udara barangkali seperti miniatur Indonesia, Kaliwangi dan wadas tumpang seperti pulau Papua dan Sulawesi, Kalitanjung yang memang luas seperti pulau Kalimantan, Bonjok Wetan pulau Jawa, Bonjok Kulon dan Karang ndadap pulau Sumatra, karena masing-masing dusun / grumbul berjauhan. Kehidupan 
masyarakatnya cukup beragam ada petani, pedagang, tukang, buruh, pegawai negeri dan TNI/Polri. Ragam seni dan budaya juga cukup unik, di Kalitanjung terdapat ebeg/kuda lumping, Bonjok wetan ada calung, obyek wisata ada pemandian belerang Kalibacin dan Bendung gerak serayu.

\section{b. Wawancara}

Untuk mendapatkan informasi secara mendalam seputar keberadaan olahraga atau permainan tradisional di wilayah tersebut, maka penggalian informasi ditujukan kepada tokoh masyarakat, sesepuh masyarakat, atau ketua adat setempat. Dengan pertimbangan bahwa di desa tersebut terdapat kelompok Islam yang masih kental dengan kepercayaan Jawa, maka ketua atau kyai kelompok Islam Kejawen tersebut sebagai sumber informasi. Berdasarkan wawancara dengan dua orang Kyai yaitu Kyai Karta Miharja, dan Kyai Muharto, dipilihlah permainan tradisional dul-dulan untuk dianalisa oleh ahli materi dan ahli pembelajaran

\section{c. Focus Group Discusion}

Tahap selanjutnya dengan melakukan diskusi kelompok terbatas (Focus Group Discusion/FGD) untuk menganalisa keunggulan dan kelemahan permainan tersebut Hal ini disesuaikan karakteristik masyarakat dan lingkungan wilayah tersebut. FGD dilaksanakan di kediaman Kepala Desa dan diikuti oleh Kepala Desa, 2 orang Kyai, 2 orang Pegiat Desa Wisata, dan 5 orang tokoh pemuda, ahli materi dan ahli pembelajaran (2 orang), serta 3 orang peneliti. Dari hasil FGD diputuskan bahwa salah satu permainan tradisional yang potensial untuk mengembangkan komponen biomotor adalah dul-dulan untuk dianalisa oleh ahli materi dan ahli pembelajaran

\section{d. Simulasi}

Penelitian ini bertujuan untuk mengetahui unsur-unsur komponen biomotor dominan yang terkandung dalam olahraga permainan tradisional, maka tahap selanjutnya adalah menganalisa permainan tersebut dengan melakukan simulasi permainan. Kegiatan Simulasi pertama dilakukan dengan melibatkan pemuda-pemudi, tokoh masyarakat, ketua adat, dan Kepala Desa. Dari hasil simulasi permainan dan penjelasan dari dua orang ketua adat/Kyai, didapatkan aturan permainan tradisional tersebut. Setelah disimulasikan tahap selanjutnya adalah pengambilan data, dengan direkam dalam video kemudian dianalisa secara deskriptif oleh 2 orang pakar (ahli pembelajaran penjas dan analisa materi)

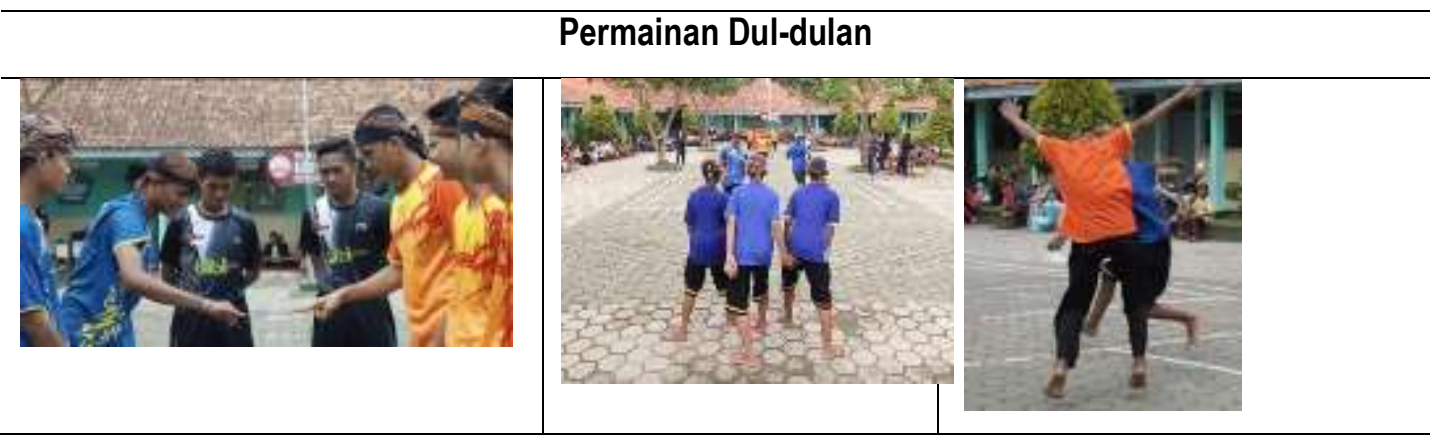




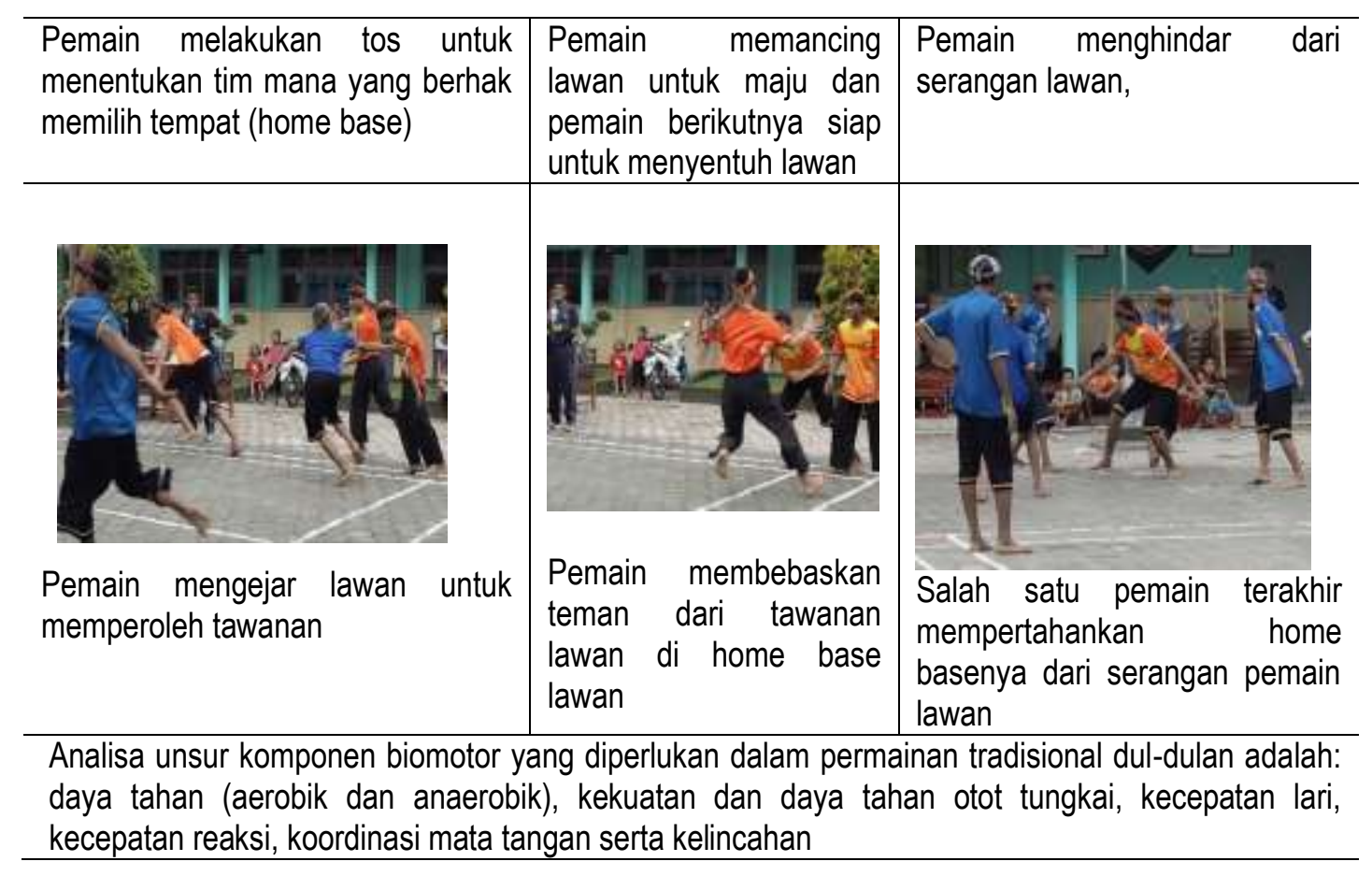

\section{KESIMPULAN}

Berdasarkan hasil penelitian dan pembahasan, komponen biomotor dominan dalam jenis permainan tradsional dul-dulan dan eteng gaplokan bisa diambil kesimpulan beberapa hal sebagai berikut; 1. Pada permainan dul-dulan terdapat unsur komponen biomotor yang dominan adalah: daya tahan (aerobik dan anaerobik), kekuatan dan daya tahan otot tungkai, kecepatan lari, kecepatan reaksi, serta koordinasi mata dan tangan kelincahan.

2. Permainan tradisional merupakan bentuk aktivitas fisik yang murah dan mudah untuk dilakukan selain itu juga memberikan rasa kegembiraan. Permainan tradisional yang bentuknya beraneka ragam dan bervariasi dalam proses pelaksanaannnya dapat memberikan respon adanya keterlibatan unsur-unsur biomotor dominan yang berbeda-beda.

3. Ditemukannya ada perbedaan respon unsur biomotor dominan tersebut, merupakan pencerminan dari keanekaragaman permainan tradisional yang ada. Untuk itu permainan tradisional bisa digunakan dalam melatih unsur biomotor yang diperlukan. Hal ini tentunya harus disesuaikan dengan tujuan pembelajaran yang diinginkan

\section{REFERENSI}

Candrawati, S., Kusuma, M. N. H., Signa, N., Eva, P., Cahya, M., \& Safira, S. (2017). Hubungan Polimorfisme Gen ACTN3 dengan Kelincahan, Daya Ledak dan Kecepatan. Jurnal Kedokteran 
Indra Jati Kusuma1', Panuwun Joko Nurcahyo², Galih Noor Alivian³ / PAJU : Physical Activity Journal 1 (1) (2019)

Brawijaya, 29 (4).

Kusuma, M. N. H., \& Julianti, K. (2015). Affecting Factor Of Swimming Exercises Based On Multi-Lateral Method To Increasing Cgnitive Intelligence Of Children. International Conference of ACPES, 1 (1).

Lutan, R. (2005). Teori Belajar Keterampilan Motorik: Konsep dan Penerapannya. Bandung: SPS UPI.

Naisaban, L. (2007). Bergembira Bersama 100 Permainan Rakyat. Jakarta: PT Grasindo.

Safari, I. (2010). Analisis Unsur Fisik Dominan Pada Olahraga Tradisional. Jurnal Kependidikan, Vol. 40. $N$.

Thomas, J., \& Nelson, K. (2001). Research Methods In Physical Activity. Champaign: IL: Humans Kinetics. 